\title{
Rancang Bangun Sistem Informasi Geografis Kabupaten Cilacap (SIKECAP)
}

\author{
Annas Setiawan Prabowo ${ }^{1}$, Lutfi Syafirullah ${ }^{2}$, Vicky Prasetia $^{3}$, Hera Susanti ${ }^{4}$ \\ ${ }^{1,2}$ Prodi Teknik Informatika, Politeknik Negeri Cilacap \\ ${ }^{3}$ Prodi Teknik Listrik, Politeknik Negeri Cilacap \\ ${ }^{4}$ Prodi Teknik Elektro, Politeknik Negeri Cilacap \\ e-mail: ${ }^{1}$ annassetiawanp@gmail.com, ${ }^{2}$ syafirullah.lutfi@gmail.com, ${ }^{3}$ vickyprasetia@gmail.com, \\ ${ }^{4}$ herasusanti86@gmail.com
}

Diterima: 01 Oktober 2020; Direvisi: 22 April 2021; Disetujui: 06 Mei 2021

\begin{abstract}
Abstrak
Pertumbuhan industri kreatif di Indonesia terus mengalami kenaikan. Industri kreatif diharapkan dapat menjadi sektor strategis yang mampu meningkatkan perekonomian di masa yang akan datang. Kesulitan yang dihadapi oleh industri kreatif terutama di Kabupaten Cilacap adalah pencarian lokasi industri kreatif yang sulit ditemukan. Industri kreatif mengalami kesulitan didalam mengenalkan produk yang dihasilkan. Berdasarkan masalah diatas perlu dibuat sistem informasi geografis yang mampu menunjukkan lokasi industri kreatif dengan akurat serta mampu membantu industri kreatif dalam mengenalkan produk yang dihasilkan. Penelitian ini menggunakan metode pengumpulan data secara deskriptif serta mengambil dari jurnal penelitian terdahulu. Metode pengembangan sistem yang digunakan menggunakan Rapid Application Development (RAD). Metode pendekatan sistem yang digunakan yaitu sistem berbasis System Development Life Cycle dengan kelebihan waktu yang lebih cepat. Pemodelan UML yang digunakan yaitu use case diagram dan activity diagram. Pengujian sistem dilakukan dengan menggunakan metode black-box testing. Hasil penelitian ini adalah sistem informasi geografis yang mampu menunjukkan lokasi industri kreatif dengan lebih cepat, serta mampu membantu industri kreatif dalam mengenalkan produk yang dihasilkan.
\end{abstract}

Kata kunci: sistem informasi geografis, industri kreatif, kabupaten cilacap

\begin{abstract}
The growth of the creative industry in Indonesia continues to increase. The creative industry is expected to become a strategic sector capable of improving the economy in the future. The difficulty faced by the creative industry, especially in Cilacap Regency, is finding the location of the creative industry which is difficult to find. The creative industry has difficulty in introducing the resulting products. Based on the above problems, it is necessary to create a geographic information system that is able to accurately indicate the location of the creative industry and is able to assist the creative industry in introducing the products produced. This study uses descriptive data collection methods and takes from previous research journals. The system development method used is Rapid Application Development (RAD). The system approach method used is a System Development Life Cycle based system with a faster excess time. UML modeling used is use case diagrams and activity diagrams. System testing is carried out using the black-box testing method. The result of this research is a geographic information system that is able to show the location of the creative industry more quickly, and is able to help the creative industry in introducing the products it produces
\end{abstract}

Keywords: geographic information system, creative industry, cilacap regency 


\section{PENDAHULUAN}

Industri kreatif merupakan sektor strategis yang diharapkan mampu meningkatkan pertumbuhan ekonomi Indonesia dimasa yang akan datang. PDB Industri kreatif tahun 2015 mencapai 852 triliun rupiah dengan pertumbuhan 4,38\% dimana industri kreatif menyumbang $7,38 \%$ terhadap total perekonomian nasional. Sektor industri kreatif meliputi periklanan, arsitektur, layanan komputer dan perangkat lunak, pasar barang seni, kerajinan, desain, industri digital, permainan interaktif, musik, seni pertunjukan dan percetakan, televisi dan radio, riset dan pengembangan, serta kuliner [1]. Salah satu kendala yang sering dihadapi industri kreatif yakni media promosi serta manajemen pelayanan konsumen akan lokasi dan informasi produk yang dihasilkan. Strategi yang perlu dilakukan oleh industri kreatif adalah melakukan perluasan dan pengembangan pasar serta melakukan perbaikan desain pengembangan produk[2].

Sistem Informasi Geografis (SIG) digunakan dalam memahami, menganalisis, dan mengelola data spasial terdistribusi yang kemudian dipetakan ke suatu wilayah geografis dimulai dengan tujuan menghasilkan peta digital. SIG menjadi alat pendukung pengambilan keputusan pengolahan data dalam bentuk spasial menjadi informasi yang berguna untuk masyarakat. SIG Geografis merupakan sistem informasi yang menggabungkan antara unsur peta geografis dan informasinya tentang peta tersebut yang dirancang untuk mendapatkan, mengelola, memanipulasi, menganalisis, memperagakan dan menampilkan data spasial untuk menyeesaikan perancangan, mengelola dan meneliti permasalahan. Penelitian tentang penggunaan Sistem Informasi Geografis bagi pelaku Usaha Mikro Kecil Menengah (UMKM) menggunakan teknologi website di kota Salatiga menghasilkan aplikasi berupa data persebaran Usaha Mikro Kecil Menengah (UMKM) di Kota Salatiga berbasis webGIS yang mampu menampilkan persebaran UMKM beserta informasi terkait UMKM tersebut [3]. Kekurangan dari penelitian ini adalah Fitur - fitur yang tersedia belum lengkap yaitu belum menyajikan informasi bagi umum dan anggota klaster dalam mengakses aplikasi ini. Penelitian serupa membahas tentang Pengembangan Informasi Klaster UMKM serta Potensi Wilayah Berbasis Peta Google Pada E-Gov.Hasil penelitian ini adalah pengembangan sistem informasi klaster UMKM serta potensi wilayah melakukan pengembangan model informasi klaster UMKM dan potensi wilayah yang mampu menyajikan informasi dasar seperti informasi aset, omset, jenis usaha [4]. Kelemahan penelitian ini adalah input data lokasi masih dilakukan dengan manual yaitu diletakkan dalam coding.

Pendataan yang dilakukan oleh Pemerintah Kabupaten Cilacap oleh Dinas Ketenegakerjaan dan Perindustrian pada tahun 2019 memiliki data IKM sejumlah 3207 IKM [5]. Data IKM tersebut didalamnya termasuk data Industri Kreatif. Pemantauan perkembangan Industri kreatif saat ini masih dilakukan secara konvensional yaitu menggunakan pendataan berbentuk buku dalam lembaran kertas. Permasalahan yang dihadapi dari sistem yang sedang berjalan yaitu pencarian lokasi industri kreatif yang memakan waktu yang lama, kurangnya informasi publik tentang jenis produk yang dihasilkan oleh industri kreatif berdasarkan kategori [6].

Penelitian ini berbeda dengan beberapa penelitian yang sudah dilakukan, penelitian ini berupa "Perancangan Sistem Informasi Geografis Industri Kreatif (Studi Kasus : Kab. Cilacap)". Aplikasi Sistem Informasi Geografis ini dapat digunakan dengan mudah dengan hanya menginputkan titik koordinat letak Industri Kreatif, sehingga dapat menampung data Industri Kreatif dalam jumlah banyak.

\section{METODE PENELITIAN}

Metode yang digunakan dalam penelitian ini terbagi menjadi dua metode pengumpulan data secara deskriptif serta metode pengembangan sistem menggunakan Rapid Application Development. Penelitian tentang sistem informasi geografis industri kreatif kabupaten Cilacap 
menggunakan beberapa tahap penelitian. Tahapan pertama dalam penelitian adalah mengumpulkan data baik data industri kreatif kabupaten cilacap dari Dinas Perdagangan dan Perindustrian serta pengumpulan data dari jurnal penelitian tentang Sistem Informasi Geografis. Tahapan selanjutnya adalah tahapan analisis data. Tahapan ini merupakan tahapan menganalisa serta mengolah data yang telah dikumpulkan menjadi informasi yang dibutuhkan dalam penelitian ini. Tahapan ketiga adalah tahapan perancangan sistem informasi geografis kabupaten cilacap berdasarkan informasi yang telah dikumpulkan dalam tahapan sebelumnya. Tahapan keempat merupakan tahapan implementasi. Tahapan ini membuat sistem informasi geografis sesuai dengan perancangan sistem. Tahapan terkahir adalah tahapan pengujian apakah aplikasi sesuai dengan perancangan, dimana pembuatan aplikasi disesuaikan dengan tujuan dari penelitian yaitu memudahkan pengguna dalam mencari lokasi industri kreatif serta memberikan informasi tentang produk-produk yang dihasilkan oleh para pelaku industri kreatif di wilayah kabupaten Cilacap. Gambar 1 adalah flowchart yang menjelaskan metode yang dilakukan dalam penelitian ini.

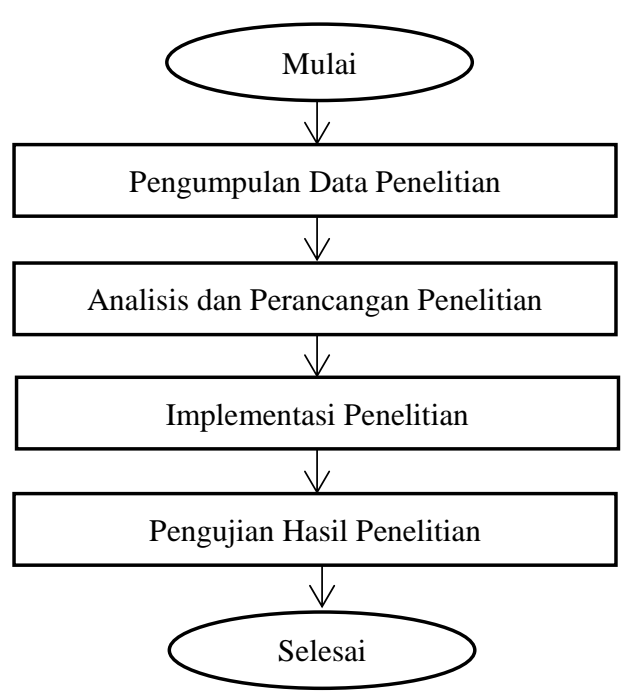

Gambar 1 Flowchart Metode Penelitian

Penelitian dilakukan di wilayah Kabupaten Cilacap dalam hal ini data diambil dari Dinas Ketenagakerjaan dan Perindustrian Kabupaten Cilacap dengan mengambil data industri kreatif serta melakukan wawancara.

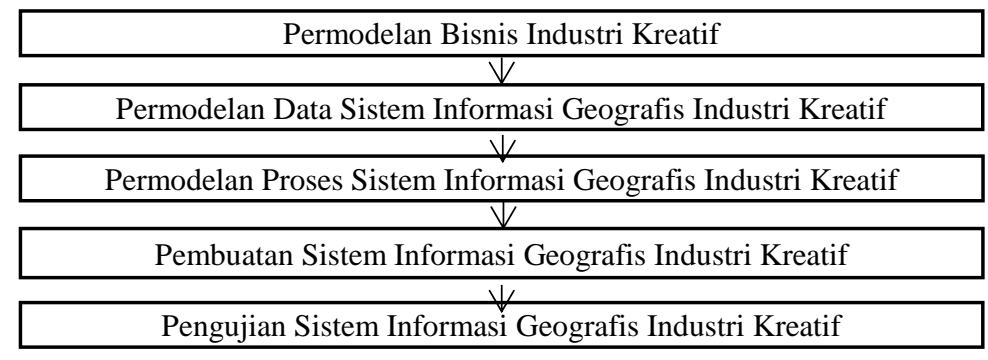

Gambar 2 Metode Pengembangan Sistem Geografis Industri Kreatif dengan RAD

Metode pengembangan sistem dalam penelitian ini menggunakan metode Rapid Application Development (RAD). Rapid Application Development (RAD) merupakan bagian dari pengembangan sistem berbasis SDLC (System Development Life Cycle) [7]. Metode pengembangan sistem RAD memiliki keunggulan dari segi kecepatan dan waktu pembuatan [8] 
[9], mengingat penelitian memiliki waktu yang terbatas. Gambar 2 menjelaskan tentang pengembangan Sistem Informasi Geografis Industri Kreatif menggunakan metode Rapid Application Development.

Tahapan dalam penelitian ini terdiri dari beberapa tahap. Tahap pertama dalam pengembangan sistem menggunakan RAD adalah pemodelan bisnis. Tahapan ini dijalankan dengan cara mengumpulkan seluruh informasi tentang data kreatif di wilayah kabupaten Cilacap diantaranya adalah nama industri kreatif, kategori industry, alamat serta lokasi koordinat yang akan digunakan sebagai geo lokasinya. Tahap permodelan data sistem informasi geografis industri kreatif dilakukan dengan pembuatan aktifitas diagram (diagram activity). Tahapan selanjutnya merupakan tahapan pembuatan sistem informasi geografis berbasis website dengan menggunakan framework codeigniter, bahasa pemrograman PHP dan Basis Data MySQL. Tahapan akhir dari pengembangan sistem adalah pengujian sistem informasi geografis menggunakan metode black-box testing. Metode Penelitian pada tahapan analisis dan perancangan menggunakan metode pengembangan sistem RAD. Use Case diagram digunakan dalam tahapan menganalisa terkait dengan kebutuhan pengguna Sistem Informasi Geografis.

Sistem yang dibuat bertujuan untuk memudahkan pengguna dalam mengoperasikan sistem informasi geografis industri kreatif. Dalam mencapai tujuan tersebut perlu dibuat analisis kebutuhan pengguna. Terdapat empat pengguna yaitu admin, petugas lapangan, industry kreatif serta visitor. Tabel 1 merupakan analisis kebutuhan berdasarkan pengguna. Gambar 3 menjelaskan tentang permodelan sistem berdasarkan analisa kebutuhan menggunakan Use Case Diagram.

Tabel 1 Analisis Kebutuhan Pengguna

\begin{tabular}{|c|c|c|}
\hline No & Pengguna & Aktifitas \\
\hline 1 & Admin & $\begin{array}{l}\text { Mengelola pengguna, mengelola data industri kreatif, mengelola kategori } \\
\text { industri, mengelola bahan baku, mengelola produk, mengelola bahan } \\
\text { baku, mengelola titik koordinat }\end{array}$ \\
\hline 2 & Petugas Lapangan & Mengelola verifikasi, mengelola industri kreatif \\
\hline 3 & Industri Kreatif & $\begin{array}{l}\text { Mendaftarkan industri kreatif, mengelola produk, mengelola lokasi } \\
\text { koordinat }\end{array}$ \\
\hline 4 & Visitor & Melihat produk Industri Kreatif \\
\hline
\end{tabular}

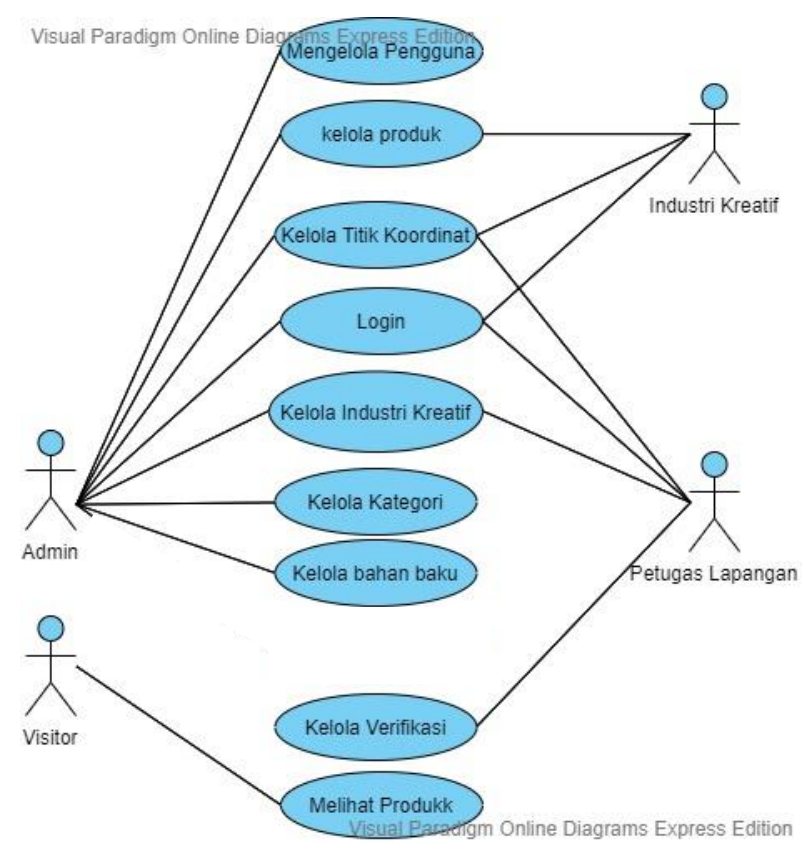

Gambar 3 Permodelan Menggunakan Usecase Diagram 
Tabel 2 Deskripsi Usecase

\begin{tabular}{|c|c|c|}
\hline No & Use Case & Deskripsi \\
\hline 1 & Mengelola Pengguna & $\begin{array}{l}\text { Sistem menampilkan aktifitas tambah update delete data pengguna } \\
\text { yang hanya bisa dilakukan oleh admin }\end{array}$ \\
\hline 2 & $\begin{array}{l}\text { Mengelola Data } \\
\text { Industri Kreatif }\end{array}$ & $\begin{array}{l}\text { Sistem menampilkan aktifitas tambah update delete data industri } \\
\text { kreatif. Hak akses diberikan kepada admin dan petugas lapangan. }\end{array}$ \\
\hline 3 & $\begin{array}{l}\text { Mengelola Kategori } \\
\text { Industri }\end{array}$ & $\begin{array}{l}\text { Sistem menampilkan aktifitas tambah update delete kategori industri . } \\
\text { Hak akses diberikan padaadmin. }\end{array}$ \\
\hline 4 & Mengelola Bahan Baku & $\begin{array}{l}\text { Sistem menampilkan pengelolaan bahan baku para pelaku industri } \\
\text { kreatif. Hanya admin yang dapat melakukan. Dapat dilakukan oleh } \\
\text { industri kreatif dan admin. }\end{array}$ \\
\hline 5 & Mengelola Produk & Sistem menampilkan pengelolaan produk. \\
\hline 6 & Mengelola Verifikasi & $\begin{array}{l}\text { Sistem menampilkan aktifitas pengelolaan verifikasi data industri } \\
\text { kreatif }\end{array}$ \\
\hline 7 & Melihat Produk & Sistem menampilkan produk. Hak akses oleh semua user. \\
\hline
\end{tabular}

\section{HASIL DAN PEMBAHASAN}

Penelitian ini menghasilkan Rancangan Sistem Informasi Geografis Industri Kreatif yang dapat dimanfaatkan oleh para pemangku kepentingan seperti pemerintah pusat maupun pemerintah daerah kabupaten Cilacap, petugas lapangan, para pelaku industri kreatif serta pelanggan produk industri kreatif. Pada Gambar 4 menjelaskan tentang login user oleh admin, industri kreatif, petugas lapangan untuk menggunakan sistem. Pendataan dan pendaftaran Industri Kreatif secara mandiri juga dapat dilakukan melalui sistem ini. Gambar 4 merupakan halaman login Sistem Informasi Geografis Industri Kreatif kabupaten Cilacap (SIKECAP )agar dapat digunakan oleh pengguna.

\section{Welcome to SIKECAP}

Sistem Informasi Geografis Industri Kreatif Kabupaten Cilacap

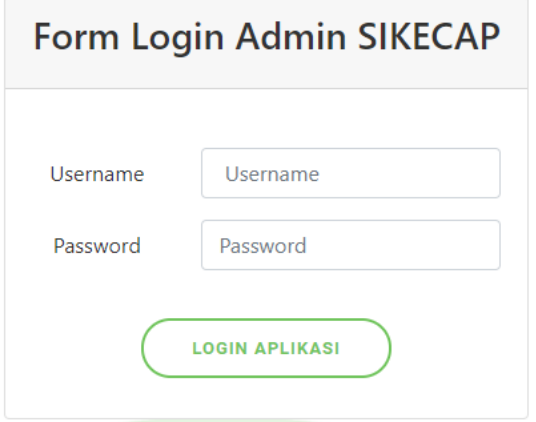

Gambar 4 Halaman Login Pengguna

Halaman login digunakan oleh admin, petugas lapangan dan industri kreatif dalam mengkases aplikasi SIKECAP. Username dan password harus benar untuk dapat menggunakan sistem ini. Jika salah satu dari username atau password salah maka sistem tidak akan dapat digunakan. Secara otomatis sistem akan memberikan notifikasi. 


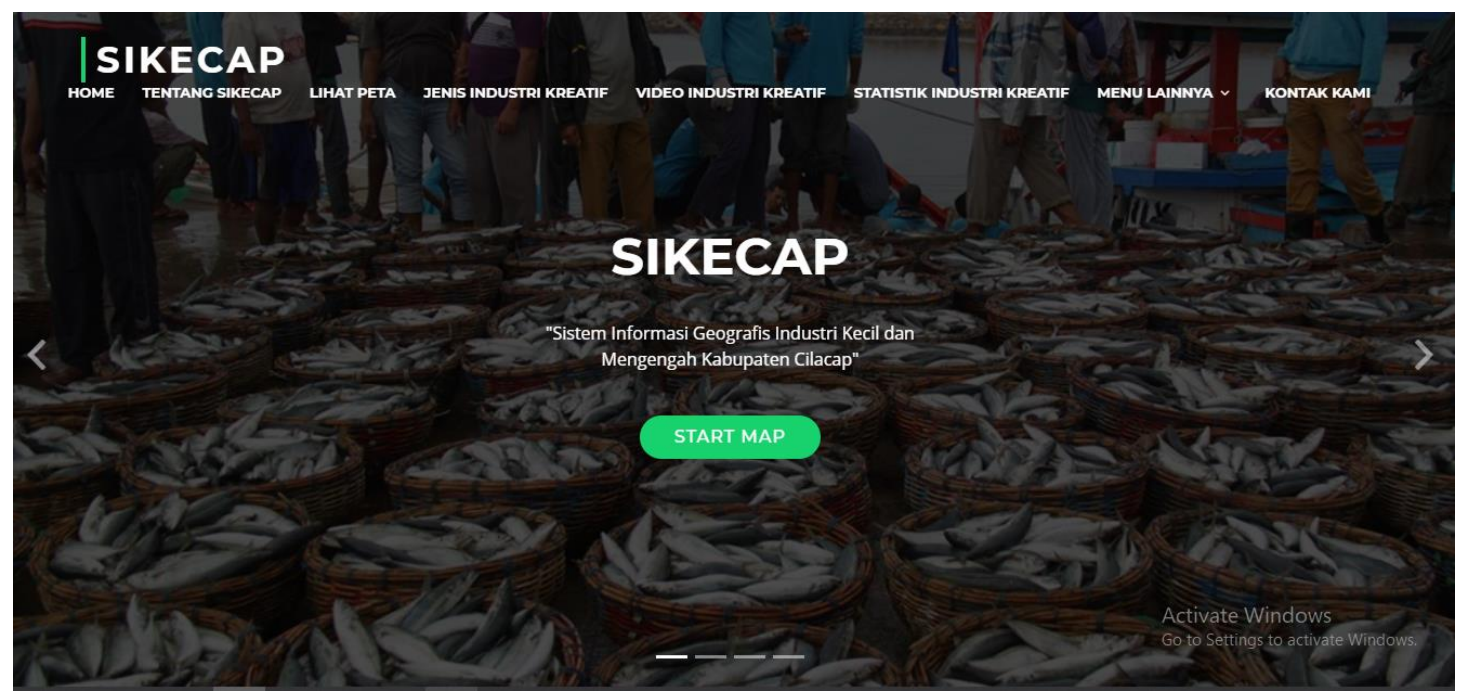

Gambar 5 Halaman Utama Sistem Informasi Geografis Industri Kreatif Kabupaten Cilacap (SIKECAP)

Halaman utama Sistem Informasi Geografis Industri Kreatif Kabupaten Cilacap berisi beberapa menu diantaranya adalah : Home, Tentang Sikecap, Lihat Peta, Jenis Industri Kreatif, Lihat Peta, Jenis industri kreatif, statistic industri kreatif, kontak kami dan menu lainnya. Gambar 5 menjelaskan tentang menu halaman utama SIKECAP. Menu utama menampilkan Peta sebaran industri kreatif kabupaten Cilacap berdasarkan lokasi. Apabila lokasi di-klik maka akan muncul detail industri kreatif. Gambar 6 merupakan peta sebaran industri kreatif kabupaten Cilacap.

PETA SEBARAN INDUSTRI KREATIF KAB. CILACAP

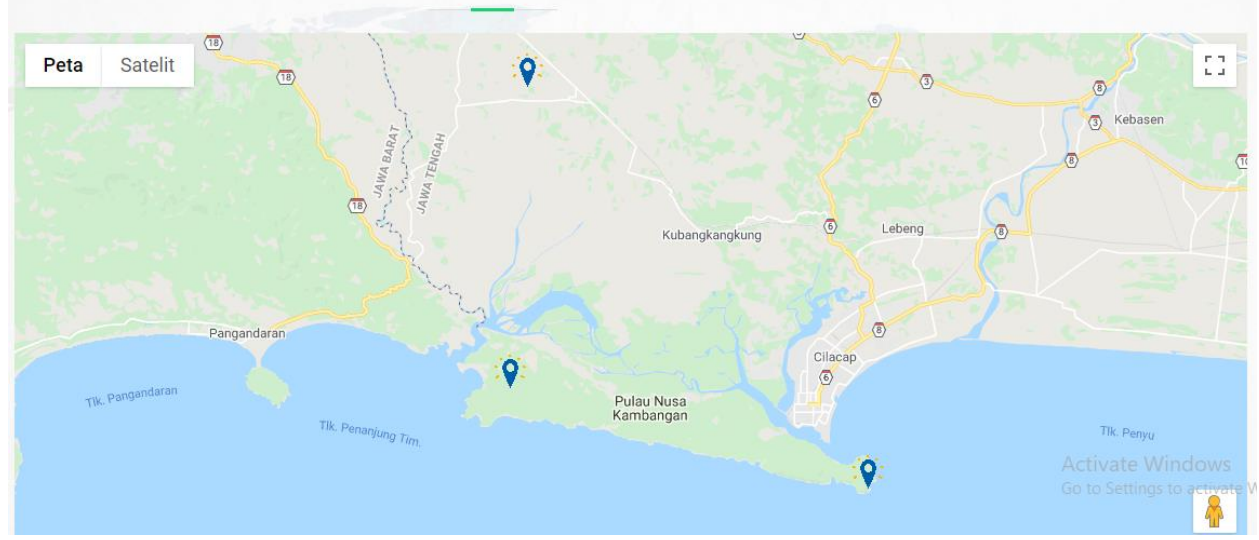

Gambar 6 Peta Sebaran Industri Kreatif Kabupaten Cilacap berdasarkan lokasi

Tabel 3 Hasil Pengujian Black-Box Testing

\begin{tabular}{lll}
\hline \multicolumn{1}{c}{ Halaman } & \multicolumn{1}{c}{ Kondisi } & Hasil \\
\hline Admin & Melakukan lihat, tambah, edit, hapus data industri kreatif & Berhasil \\
Petugas lapangan & Melakukan lihat, tambah, edit, hapus verifikasi & Berhasil \\
Industri Kreatif & Melakukan lihat, tambah, edit, hapus data produk & Berhasil \\
\hline
\end{tabular}

Sistem Informasi Geografis Industri Kreatif memiliki pengguna admin, petugas lapangan serta industri kreatif. Admin memiliki hak akses dalam mengelola data industri kreatif 
beserta letak koordinat titik lokasinya. Sistem ini telah diuji dengan menggunakan blackbox testing [10] didapatkan hasil seperti tabel 2.

\section{KESIMPULAN}

Kesimpulan dari penelitian rancang bangun sistem informasi geografis industri kreatif ini adalah bahwa sistem yang dihasilkan dapat membantu pencarian lokasi industri kreatif dengan lebih cepat berdasarkan lokasi sesuai titik koordinat, sehingga memudahkan calon pelanggan untuk datang ke lokasi. Informasi mengenai produk yang dihasilkan dari pelaku industri kreatif memudahkan calon pelanggan untuk melihat berbagai produk yang dihasilkan dari pelaku industri kreatif.

\section{SARAN}

Berdasarkan hasil evaluasi Sistem Informasi Geografis Industri Kreatif Kabupaten Cilacap, perlu adanya penyempurnaan sistem terkait dukungan grafis yang lebih interaktif dalam menampilkan lokasi industri kreatif.

\section{UCAPAN TERIMAKASIH}

Kami mengucapkan terimakasih kepada Direktorat Riset dan Pengabdian Kepada Masyarakat Direktorat Jenderal Penguatan Riset dan Pengembangan Kementerian Riset dan Teknologi / Badan Riset dan Inovasi Nasional Sesuai dengan Perjanjian Penugasan Pelaksanaan Penelitian Nomor : 091/SP2H/LT/DRPM/2020 yang telah mendanai penelitian ini. Terimakasih kepada Politeknik Negeri Cilacap dan Dinas Ketenagakerjaan dan Perindustrian Kabupaten Cilacap yang telah membantu pelaksanaan penelitian.

\section{DAFTAR PUSTAKA}

[1] Badan Ekonomi Kreatif, "Data Statistik dan Hasil Survei," 2018.

[2] Z.Abidin and L.A.Permadi, "Strategi Pengembangan Industri Kreatif Sektor Kerajinan Perhiasan Mutiara di Kota Mataram," J. Magister Manaj. Univ. Mataram, pp. 1-16, 2018.

[3] M.Gustavianto, A.Suprayogi, and A.Wijaya, "Aplikasi Sistem Informasi Geografis (Sig) Persebaran Usaha Mikro Kecil Menengah (Umkm) Berbasis Web (Studi Kasus : Kota Salatiga)," J. Geod. Undip, vol. 5, no. 1, pp. 49-56, 2016.

[4] J.A.Rozaq et al., "Pengembangan Informasi Klaster Umkm Dan Potensi Wilayah Berbasis Peta Google Pada E-Gov," pp. 2-7, 2018.

[5] A S.Prabowo and N.W.Rahadi, "Sistem Informasi Industri Kecil Menengah Berbasis Sentra Menggunakan Metode Rapid Application Development," Infotekmesin, vol. 11, no. 1, pp. 37-43, 2020.

[6] Dinas Ketenagakerjaan dan Perindustrian Kabupaten Cilacap, "Data Industri Kecil Menengah Kabupaten Cilacap," 2019.

[7] B A.Matjik and J.F.Andry, "Perancangan Sistem Inventory dengan Metode Rapid Application Development (Studi Kasus PT XYZ)," JOINS (Journal Inf. Syst., vol. 4, no. 2, pp. 140-147, 2019.

[8] S.Kosasi, "Penerapan Rapid Application Development Dalam Sistem Perniagaan 
Elektronik Furniture," vol. 2, no. 4, pp. 265-276, 2015.

[9] R.Trimahardhika and E.Sutinah, "Penggunaan Metode Rapid Application Development Dalam Perancangan Sistem Informasi Perpustakaan," vol. 4, no. 2, pp. 249-260, 2017.

[10] P.R.S, Pengujian Black box. 2005. 